\title{
Holocene high-altitude vegetation dynamics on Emi Koussi, Tibesti Mountains (Chad, Central Sahara)
}

\author{
Michèle Dinies ${ }^{1}$, Lena Schimmel \& Philipp Hoelzmann \\ Freie Universität Berlin, Institute of Geographical Sciences, Berlin, Germany
}

Stefan Kröpelin

University of Cologne, Institute of Prehistoric Archaeology, Africa Research Unit, Cologne, Germany

Frank Darius

Technische Universität Berlin, Institute for Ecology, Berlin, Germany

Reinder Neef

German Archaeological Institute (DAI), Scientific Department of the Head Office, Berlin, Germany

\begin{abstract}
High mountains are sensitive to climate change. Holocene lake remnants witness to the last Saharan Humid Period (SHP) in the Tibesti, the highest mountains of the Sahara ( $>3000 \mathrm{~m}$ asl). The impact of Holocene climatic change on the terrestrial montane ecosystems, however, is largely unknown. Palynological investigations on a palaeolake sequence from the summit caldera of the Emi Koussi, the highest volcanic complex of the Central Sahara, were performed to address this issue. Based on charred plant particle concentrations, the age depth model indicates a Holocene age of the palaeolake (c. 9500-5500 cal yr BP). Shifts in the vegetation composition indicate altered climatic conditions: high proportions of Poaceae and fern as well as highly fluctuating Artemisia frequencies characterize the SHP, strongly dominating Ephedra distachya-type proportions reflect the present vegetation, evidencing distinctly decreased humidity. The missing mass expansion of tropical tree taxa into the summit zone meanwhile points to persisting low temperatures during the Holocene. The absence of Mediterranean tree taxa during the SHP indicates that migration from the Mediterranean to the southern Sahara was not possible. Hence, a survival of Mediterranean tree taxa within micro-refugia may also be excluded. An exception is Erica (arborea) which expanded only during the Middle Holocene, relying on relict populations. Increased precipitation at persisting lower temperatures thus shaped the
\end{abstract}

\footnotetext{
${ }^{1}$ Other affilitation: German Archaeological Institute (DAI), Scientific Department of the Head Office, Berlin, Germany
} 
high altitudinal ecosystems during the SHP, triggering modifications in the vegetation composition. The ecosystem type itself, a montane steppe, remained. This is in clear contrast to the contemporaneous marked biome changes in the surrounding Saharan plains.

\subsection{INTRODUCTION}

Due to their positions amidst today's largest hot desert, the mountain complexes Hoggar and Tibesti in the central Sahara are exceptional regions, resembling islands of increased biodiversity. Even though the altitudinal change in precipitation and temperature leads to more mesic conditions at higher elevations, there is no montane tree belt in these Central Saharan massifs, distinguishing them from the tropical mountains in East Africa as well as from the Mediterranean mountain ranges in the north. A combination of aridity and low temperatures is claimed to prevent major tree growth in the Hoggar and Tibesti, fostering at their summit a vegetation formation dominated by species of the genera Ephedra, Artemisia and Pentzia, called 'pseudo-steppe' or 'steppe culminale' (e.g. Maire and Monod 1950; Messerli and Winiger 1992; Ozenda 1991; Quézel 1965). The steppe culminale fits the criteria of paleartic steppes characterized by (a) the dominance of herbs, mainly grasses with high chamaephyt proportions in some regions (b) more than $10 \%$ vegetation cover (c) occurring in climates too dry for taller woody vegetation and at least occasionally affected by frost (Wesche et al. 2016). This definition thus includes the naturally occurring grasslands of the Mediterranean and of the subtropical-tropical arid zones as steppe, similar to the definition of Le Houérou (2001, 2009).

Because of the strong dominance of chamaephyts, the steppe culminale of the Tibesti may be assigned to the desert steppes, characterized by vegetation cover of only $10-25 \%$ with often increased dwarf shrub proportions, a vegetation formation mediating to subtropical deserts (cf. Wesche et al. 2016). The present heterogenous biogeographical composition of the Central Saharan montane ecosystems points to multiple floristic relations: inner Saharan, Sahelian, Afroalpine East African, and links to the Mediterranean phytoregion. The latter are documented by Mediterranean woody plants at altitudes higher than $1500 \mathrm{~m}$ asl (Cupressus dupreziana, Erica arborea, Olea europaea subsp. laperrinei and Rhus tripartite) and numerous annuals and perennials. However, most of these woody taxa only occur in the Hoggar mountains, compliant with higher proportions of Mediterranean dwarf shrubs and annuals. The more northerly position of the Hoggar massif in comparison to the Tibesti and thus (closer) proximity to the Mediterranean phytoregion accounts for this difference (Maire 1935; Maire and Monod 1950; Médail and Quézel 2018; Ozenda 1991; Quézel 1965).

As to the African Humid Period, several dated palynological and anthracological investigations in the surrounding plains of the Eastern and Central Sahara provide evidence of profound ecosystem changes, with tropical plant taxa migrating some $500 \mathrm{~km}$ northwards compared to their present day distribution, thus as far north as the Tibesti or even further north (Gabriel 1977; Haynes et al. 1989; Hély and Lézine 2014; Jahns 1995; Lézine 2017; Maley 1981; Ritchie et al. 1985; Ritchie 1987; Ritchie 1994; Ritchie and Haynes 1987; Schulz 1987, 1991; Schulz 1991; Mercuri et al. 1998; Mercuri 1999; Mercuri and Grandi 2001; Neumann 1989; Trevisan et al. 1998; Watrin et al. 2009). There is, however, no clear evidence of a similar distinct southward migration of Mediterranean plant taxa into the Central Saharan plains during the Holocene.

An intensified and northwards expanded summer monsoon is supposed to be the main humidity source (Kutzbach 1981). Other atmospheric patterns are assumed to have contributed as well, such as e.g. seasonal tropical plumes and extratropical troughs (Dallmeyer et al. 2020; Knippertz 2005; Maley 2000; Skinner and Poulsen 2016), and interactions of extratropic cyclones with the monsoonal system, either with or without overlaps (e.g. Baumhauer 2004; Rogerson et al. 2019) or with additional interferences of moisture from the Indian Ocean (Mercuri et al. 2018) are 
discussed. Feedback mechanisms additionally seem to play a role. In models, interactive coupling between atmospheric and oceanic dynamics as well as land surface amplify the African monsoon (e.g. Braconnot et al. 1999, 2007; Claussen and Gayler 1997; Claussen et al. 1999; Kutzbach and Liu 1997; Pausata et al. 2016). The influence of land cover feedbacks is controversial (e.g. Braconnot et al. 1999 vs. Braconnot et al. 2007), however a positive feedback seems probable (e.g. Krinner et al. 2012).

Palaeolake remnants in the montane belt of the Tibesti and Hoggar massifs document the impact of increased precipitation during the African humid period (e.g. Jäkel and Geyh 1982; Maley 1981; Médail and Quézel 2018). The vegetation response however remains vague, because to date only single or few palynological samples scattered throughout the Central Saharan Mountains have been investigated, allowing only very punctual insights. Samples of the Hoggar tentatively dated to the beginning of the Pleistocene show high proportions of temperate and plant taxa, interpreted as relict woodlands of the Tertiary. During the Middle and Late Pleistocene, the proportions of tropical plant taxa as well as types representing the Saharan desert vegetation increased, while Mediterranean and temperate taxa persisted, however with decreasing importance. This led to the hypothesis that the desert vegetation established successively in the plains and thus acted as a barrier, isolating the mountain ranges, which however were connected by hydrogeographic networks activated during periods of increased humidity (Rossignol and Maley 1969). As to the African Humid Periods, the involvement of Mediterranean taxa in the Hoggar/Tassili and Tibesti mountain complexes remains ambiguous. Some authors suggest an expansion of Mediterranean or even temperate tree taxa in the Central Saharan mountains, while a re-investigation in the Hoggar and analyses on lake remnants in the Tibesti revealed only the few Mediterranean tree taxa still present today (e.g. Alimen et al. 1968; Gabriel 1977; Quézel 1958; Quézel 1965; Maley 1981; Maley 2000; Prentice et al. 2000; Medail and Quézel, 2018 versus Thinon et al. 1996 and own investigations).

Here, we present the first pollen diagram encompassing the period c. 9500-5500 cal yrs $\mathrm{BP}$, based on palynological investigations of a ${ }^{14} \mathrm{C}$-dated sediment sequence from the deepest subcaldera of the highest volcanic shield complex, the Emi Koussi at about $3000 \mathrm{~m}$ asl. This analysis complements existing single sample investigations from various different geomorphological contexts. Relying on the new sequence, we will: a) present a chronology of the investigated lake remnant based on ${ }^{14} \mathrm{C}$-dates of organic material, b) indicate Holocene vegetation fluctuations at these highest altitudes and c) deduce climatic configurations from these vegetation reconstructions.

\subsection{REGIONAL SETTING}

\subsubsection{Geomorphology}

The Tibesti massif is one of the world's major and most significant examples of intracontinental volcanic provinces and covers more than $100,000 \mathrm{~km}^{2}$ (Ball et al. 2019). Intense volcanic activity began as early as the Oligocene and intensified during the Quaternary (Deniel et al. 2015; Gourgaud and Vincent 2004). The Emi Koussi is the largest volcano of the entire Tibesti Volcanic Complex, with a basal diameter from 60 to $80 \mathrm{~km}$ and a summit caldera of 9-12 km in diameter. Altitude differences vary between $c .3000 \mathrm{~m}$ compared to the Bodélé depression in the south and c. 2300-2900 $\mathrm{m}$ to the Serir Tibesti in the north (Pachur and Altmann 2006). A succession of three volcanic sequences between 2.4 and 1.3 Ma formed the Emi Koussi volcano and each is related to the collapse of a caldera. Era Kohor is the youngest caldera that was formed during the last sequence (Gourgaud and Vincent 2004). Basalts overlaying Terminal Pleistocene to Holocene limnic sediments in the Emi Koussi caldera indicate volcanic eruptions until the recent past (Messerli 1972). Seismic activities are recorded even nowadays. Groundwater-coupled processes 
like solfatars/fumaroles and hot springs are still active on the eastern slopes of Emi Koussi (Pachur and Altmann 2006).

\subsubsection{Climate}

In the plains surrounding the Tibesti, hot desert climates (BWh; Köppen 1918) prevail, whereas in the mountains the climatic conditions change due to the adiabatic lapse rate to cold desert climates (BWk) with mean annual temperatures below $18^{\circ} \mathrm{C}$. Climate data are not available for the Emi Koussi, but some meteorological data from lower locations indicate the 'classical' precipitation increase and temperature decrease with increasing altitudes. Rainfall at the Trou au Natron at $2450 \mathrm{~m}$ asl, thus $1000 \mathrm{~m}$ below the sampled Emi Koussi lake remnant, amounts to an average annual precipitation of $93.3 \mathrm{~mm}$ and a mean annual temperature of $13.5^{\circ} \mathrm{C}$ (Gavrilovic 1969). The few data allowing vague insights into the distribution throughout the year indicate a precipitation maximum during May and another during August, with highest monthly means during July (Maire and Monod 1950). For the highest altitudes of the Emi Koussi, precipitation estimations based on single measurements and deduced from altitude, geomorphology and vegetation range from 50 to $150 \mathrm{~mm}$ per year (Wininger 1972, Figure 1, Vegetation map). In contrast to the lower mountains and plains that are mainly affected by monsoonal summer precipitation, the high altitudes seem to profit from orographic, frequent but minor precipitations. Coupled with clouds, this effective moisture source propagates plant growth (Quézel 1958).

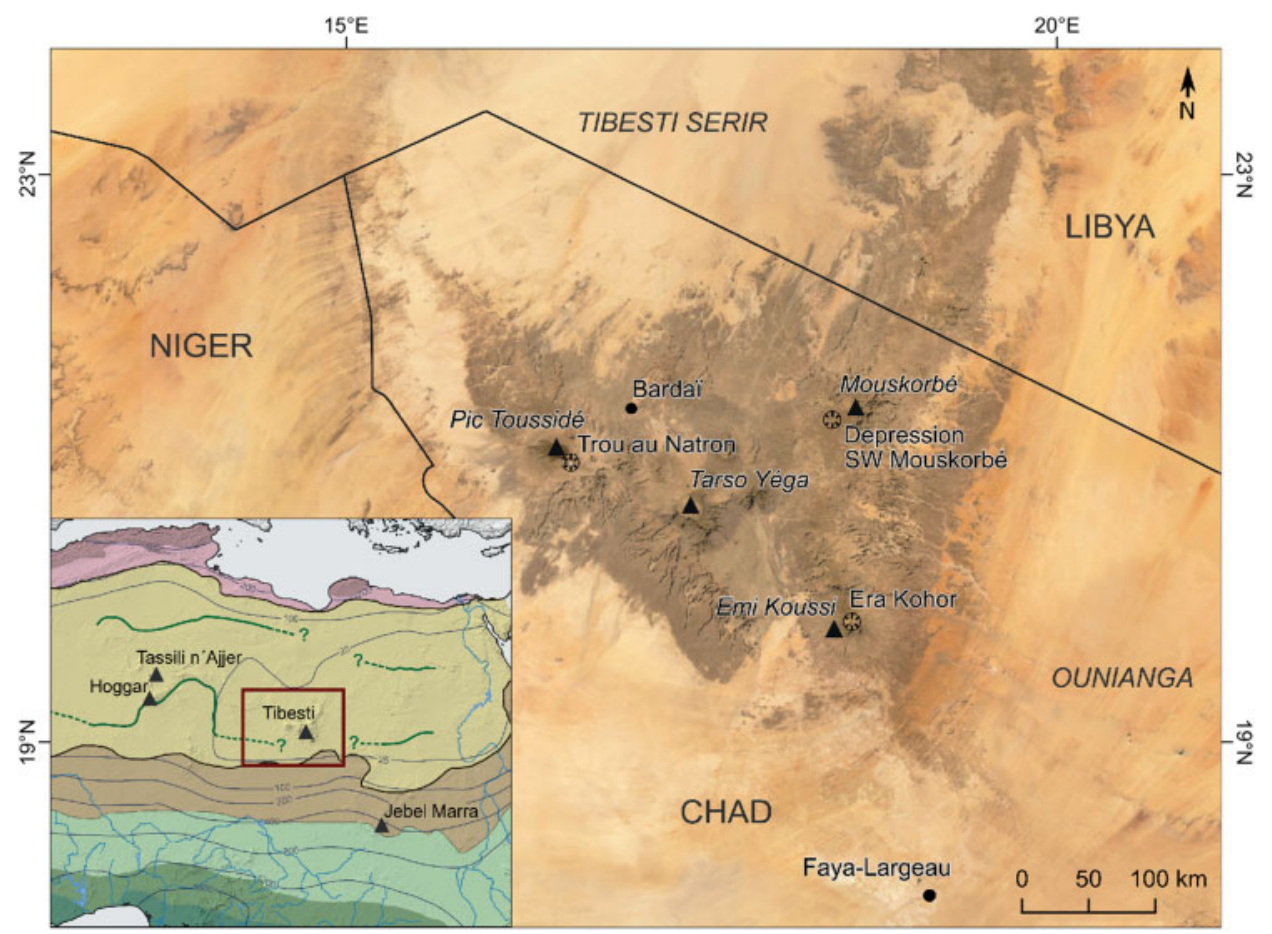

Figure 1. Satellite image (Esri World Imagery) of the Tibesti massif and its surrounding plains, Central Sahara. Inlet map: Schematic map of the vegetation zones (centres of endemism: III - Sudanian, VII - Mediterranean, and the regional transition zones: XI - Guinea-Congolia/Sudania, XVI - Sahel, XVII - Sahara, XVIII - Mediterranean/Sahara), following White (1983). The reconstructed northern limits of Sudanian and Sahelian plant taxa during the SHP are indicated as green lines (Neumann 1989; Schulz 1991). Isohyetes (in grey) are from Railsback et al. (2016). 


\subsubsection{Today's vegetation of the Tibesti}

After Maire and Monod (1950), Quézel (1958), Ozenda (1991) and Médail and Quézel (2018), three main altitudinal belts can be distinguished in the Tibesti and Hoggar Mountains: a SaharanTropical belt similar to the contracted vegetation surrounding the mountains, followed by a montane Saharan-Mediterranean belt with increasingly diffuse plant cover, and a summit zone. The generalized vegetation map after Quézel $(1958,1964,1965)$ shows this altitudinal controlled vegetation distribution on the Emi Koussi volcano itself (Figure 2).

(1) Saharan-Tropical desert vegetation of the plains: contracted desert vegetation with Panicum turgidum and Acacia ehrenbergiana dominates.

(2) Saharan-Tropical belt up to $c .1700 \mathrm{~m}$ asl: the vegetation resembles the desert vegetation of the surrounding plains, with Sahelian plant taxa such as acacias (A. tortilis var. raddiana, A. laeta, A. stenocarpa), Maerua crassifolia and Capparis decidua in the wadis, and Hyphaene thebaica and Salvadora persica bordering them. Together with a grassy vegetation formation in depressions or runnels (Aristidia funiculata - Indigofera sessiliflora formation), they are supposed to represent remnants of plant formations that expanded northwards during the African Humid Period (Médail and Quézel 2018).

(3a) Lower montane zone of the Saharan-Mediterranean belt, c. 1700-2500 m asl: in this zone the Sahelian vegetation fades out, and the plant cover becomes increasingly diffuse. Acacia stenocarpa and A. laeta, different Ficus species, Grewia tenax, Rhus, Capparis spinosa and Boscia salicifolia grow in the wadis. Montane Aristida grasslands (3b1) cover the surfaces between the wadis, with Linaria and Helianthemum as characteristic taxa. The two Acacia species form the upper tree line at altitudes of 1800-2300 m asl, depending on the exposition, while dwarf grown acacias may even reach $200 \mathrm{~m}$ higher (Messerli 1972; Quézel 1965). As to the Sahelian affinity of the acacias, temperature is claimed as the limiting factor for tree growth. Yet, aridity seems to be a relevant factor as well: in the Hoggar mountains relict stands of Olea europaea subsp. laperrinei trees grow in caves at $2700 \mathrm{~m}$ asl, and at the Emi Koussi Erica arborea grows in ravines between 2500 and $3000 \mathrm{~m}$ asl, indicating that theoretically these Mediterranean trees should constitute the upper timber line at higher altitudes or even cover the highest summit. Quézel (1965) thus assumed that these and other Mediterranean (and Temperate) elements disappeared $4000-5000$ years ago as a result of aridification.

(3b2) Upper montane zone of the Saharan-Mediterranean belt (steppe culminale), above c. $2500 \mathrm{~m}$ asl: dwarf shrubs prevail at these highest altitudes. While in the Hoggar mountains Artemisia herba-alba (Seriphidium herba-alba (Asso) Sojak), Artemisia campestris (subsp. glutinosa (Besser) Blatt.), Ephedra major Host and Pentzia monodiana Maire form these summit steppes, endemic counterparts, Artemisia tilhoana Quézel and Ephedra tilhoana Maire, replace them, with Pentzia monodiana, Ballota hirsuta and Lotus tibesticus accompanying them as characteristic species. Euphorbia granulata, Erodium oreophilum, Campanula bordesiana, Helianthemum lippi and Helichrysum monodianum are also common in these steppes. This is supposed to represent a vegetation formation with a long-lasting Quaternary history (Quézel 1958, 1965).

\subsection{MATERIALS AND METHODS}

\subsubsection{Sampling}

Within the Era Kohor caldera, palaeolake remnants are preserved at the NW slopes, covered by volcanic talus material (Figures 2 and 3). These diatomaceous sediments exhibit a thickness of $145 \mathrm{~cm}$ and were sampled at an altitude of $2796 \mathrm{~m}$ asl (top of the sampled sequence; 


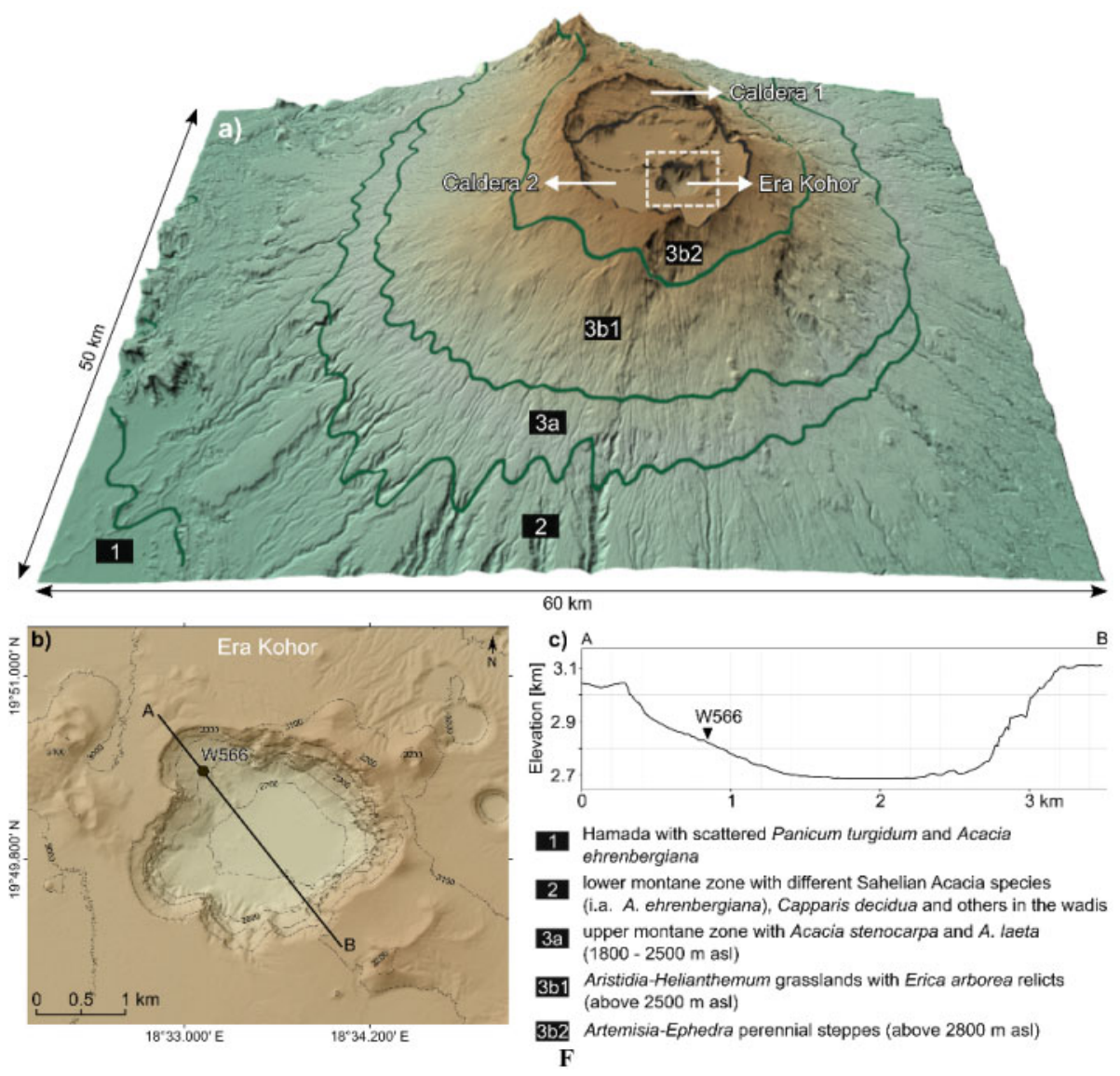

Figure 2. a) Digital elevation model (DEM) of the Emi Koussi shield volcanic complex with the three summit calderas after Gourgand and Vincent $(2004)$ and the generalized vegetation zones after Quezel $(1958 ; 1964 ; 1965)$ and Maire and Monod $(1935,1950)$. b) DEM of the Era Kohor caldera with the position of section W566 c) NW-SE profile across the Era Kohor caldera.

$\left.19^{\circ} 50.376^{\prime} \mathrm{N}, 18^{\circ} 33.177^{\prime} \mathrm{E}\right)$, some $130 \mathrm{~m}$ above the present crater floor. The desiccated sediments (diatomite) were sampled in subsequent monoliths (W566-1 to W566-7; Figure 2). Sub-sampling of the monoliths was undertaken at $1 \mathrm{~cm}$ sample intervals where possible, after export of the monoliths to the laboratory. However, some monoliths did not reach the laboratory intact and for these segments a single bulk sample was taken.

\subsubsection{Preparation of pollen samples and charred plant particles concentrates for ${ }^{14}$ C-dating}

In a first step, samples at intervals of about $10 \mathrm{~cm}$ were prepared. Pollen preservation proved highly variable throughout the profile. Subsequently the intervals with pollen preservation were chosen for further palynological investigations. Samples were treated following common acid/base, heavy liquid and acetolysis protocols, thoroughly washing the samples with distilled water after each treatment (Eisele et al. 1994; Faegri and Iversen 1989; Moore et al. 1991; 
Nakagawa et al. 1998). A volume of $10 \mathrm{~cm}^{3}$ sediment (diatomite) was prepared, adding marker spores (Stockmarr 1971).

Pollen concentrations were prepared applying a combination of different protocols (Chester and Prior 2004; Brown et al. 1992; Regnéll and Everitt 1996; Nakagawa et al. 1998; Vandergoes and Prior 2003; Piotrowska et al. 2004) with the following preparation steps: (1) Treatment with $\sim 10 \% \mathrm{HCl}$ (heated), (2) Treatment with $\sim 10 \% \mathrm{KOH}$ (heated), (3) Dense-media separation with sodium-polytungstate (SPT; $\sim 2.1 \mathrm{~g} / \mathrm{cm}^{3}$ ), (4) Treatment with $12 \mathrm{M} \mathrm{H}_{2} \mathrm{SO}_{4}$ for $2 \mathrm{~h}$, with $1.2 \mathrm{M}$ $\mathrm{H}_{2} \mathrm{SO}_{4}$ for $3 \mathrm{~h}$ (heated), (5) Microscopic analysis of the residues to decide on the next steps for the processing procedure, (6) Density separation $\left(1.6-1.2 \mathrm{~g} / \mathrm{cm}^{3}\right)$ with $\mathrm{CsCl}$ or repeated with 2.1 $\mathrm{g} / \mathrm{cm}^{3}$ SPT, with microscopic control of the potential different phases, (7) Sieving $(<6 \mu \mathrm{m})$.

Pollen slides were analysed using a transmitted light microscope (Leica DMRB) with 400 $1000 \times$ magnification. Pollens were identified by using the reference collection of the DAI (Deutsches Archäologisches Institut, Berlin, Germany), electronic photographs of the African Pollen Database (downloaded in 2012, www://medias.obs-mip.fr/apd) and published pollen atlases (Bonnefille and Riollet 1980; El-Ghazali 1993; Reille 1992).

\subsection{RESULTS}

\subsubsection{Lithostratigraphy and radiocarbon dating of W566}

The diatomite is faintly laminated in its entity, structured by oxidized bands, mainly ochre, some of them sustaining (Figure 3).

Six samples of the W566 sequence were radiocarbon dated (Table 1). The total carbon content of the diatomaceous sediments is generally extremely low and in consequence the datable amount of organic carbon in the prepared concentrates is also low. Macroscopic charred plant remains were not found in the sampled sequence. Thus, concentrates of microscopic charred plant particles were prepared for ${ }^{14} \mathrm{C}$-dating to enrich organic carbon for the necessary minimum mass of c. $0.1 \mathrm{mg}$ to produce reliable ages. However, below $0.1 \mathrm{mg} \mathrm{C}$ uncertainty increases correspondingly (Kutschera 2016), in addition the risk of contamination during sample preparation rises with decreasing sample mass. The sample with only $0.04 \mathrm{mg} \mathrm{C}$ (Poz-12905) has been excluded from calculations of the age depth model because of the methodological uncertainties, as in other investigations (e.g. Parker et al. 2004). To establish an age depth model, rbacon, a Bayesian approach with an implemented outlier analysis was chosen (version 2.4.3; Blaauw and Christen 2011). The basal $10 \mathrm{~cm}$ were devoid of datable organic material, the ages for these $10 \mathrm{~cm}$ were thus extrapolated. With these first absolute datings of the diatomite of the Era Kohor caldera, we prove a Holocene age of the lake remnant.

\subsubsection{Pollen sum and diagram}

The pollen sum varies between 63 and 910, with 304 on average. It includes all terrestrial types as well as monolete fern spores. Ferns are supposed to have been common on terrestrial sites during the African Humid Period. Similarly, ferns were included in the main sum in earlier investigations in the Tibesti (Maley 1981) and in Yemen (Lézine et al. 2007). Aquatics and other spores are excluded. The pollen sum strongly depends on the pollen concentration and preservation of the respective sample: very low pollen concentrations and/or higher proportions of corroded pollen resulted in part in low pollen sums. The diagram was drawn with Tilia (Grimm 2020). The pollen types are grouped according to their ecology in representatives of desert vegetation (of the plains), altitudinal steppes, thorn (and deciduous) savanna, and riparian and water vegetation. 
Table 1. Radiocarbon dates from section W566 from the Era Kohor caldera. The ${ }^{14} \mathrm{C}$ dates were calibrated with OxCal. The coverage of the different dated organic components is indicated as percentage values for each sample respectively.

\begin{tabular}{|c|c|c|c|c|c|}
\hline Lab-Nr. & $\begin{array}{l}\text { Depth }(\mathrm{cm}) \text { from } \\
\text { top of W566 }\end{array}$ & $\begin{array}{l}{ }^{14} \mathrm{C} \text { yrs } \\
\mathrm{BP}\end{array}$ & $\begin{array}{l}\text { cal yrs BP } \\
\text { (2sigma) }\end{array}$ & $\begin{array}{l}\text { Material } \\
\text { dated }\end{array}$ & $\mathrm{mg} \mathrm{C}$ \\
\hline Beta441716 & $0-15$ & $4720 \pm 30$ & $5320-5580$ & $\begin{array}{l}90 \% \text { charred plant } \\
\text { particles, } 10 \% \text { tissues } \\
\text { and pollen }\end{array}$ & no data \\
\hline Poz122314 & $33-36$ & $7480 \pm 50$ & $8180-8380$ & $\begin{array}{l}90 \% \text { charred plant } \\
\text { particles, } 10 \% \text { probably } \\
\text { limnic tissues }\end{array}$ & 0.3 \\
\hline Poz122366 & $95-96$ & $7700 \pm 40$ & $8400-8590$ & $\begin{array}{l}85 \% \text { charred plant } \\
\text { particles; } 10 \% \\
\text { minerogenic particles; } \\
5 \% \text { algae remains }\end{array}$ & 0.8 \\
\hline Beta441715 & $123-125.5$ & $8360 \pm 40$ & $9150-9490$ & $\begin{array}{l}90 \% \text { charred plant } \\
\text { particles, } 10 \% \text { tissues } \\
\text { and pollen }\end{array}$ & no data \\
\hline Poz125905 & $132-134$ & $7330 \pm 170$ & $7790-8460$ & $\begin{array}{l}80 \% \text { charred plant } \\
\text { particles; } 10 \% \\
\text { minerogenic particles; } \\
10 \% \text { tissues and pollen }\end{array}$ & $\begin{array}{l}0.04 \text { not } \\
\text { considered }\end{array}$ \\
\hline Poz122367 & $136-137$ & $7510 \pm 50$ & $8190-8400$ & $\begin{array}{l}80 \% \text { charred particles, } \\
20 \% \text { minerogenic } \\
\text { particles }\end{array}$ & 0.35 \\
\hline
\end{tabular}

\subsection{DISCUSSION}

\subsubsection{Age-depth model}

The sequence of the five ${ }^{14} \mathrm{C}$-dates clearly indicates a Holocene age of the lake sediments in the Era Kohor subcaldera of the Emi Koussi. Considering the distribution of the ${ }^{14} \mathrm{C}$-dates in respect to age versus depth, two possibilities can be proposed: (a) The ${ }^{14} \mathrm{C}$-date at $33-36 \mathrm{~cm}$ (Poz122314) exhibits nearly the same age as the lowest sample (Poz-122367). This can be interpreted as indicating very high sedimentation rates, about $1 \mathrm{~m}$ during a few centuries around $8200 \mathrm{cal}$ yr BP. The uppermost sample at $0-15 \mathrm{~cm}$ dating to about $5400 \mathrm{cal} \mathrm{yr}$ BP, would thus point to a marked hiatus between the basal metre and the upper $30 \mathrm{~cm}$. (b) Assuming approximately constant sedimentation rates, the dates at $33-36 \mathrm{~cm}$ (Poz-122314) has to be considered as too old. As the lithology seems uniform and there are no distinct features indicating a hiatus in the uppermost $30 \mathrm{~cm}$, we decided to consider possibility (b).

Age-depth models can be approached by linear inter- and extrapolation or by using e.g. Bayesian statistics. The latter method is based on a constrained ordering of the ${ }^{14} \mathrm{C}$-dates and simulating numerous different accumulations in between dated depths. Especially for sequences with low dating densities as well as dating scatter and outliers, a Bayesian approach is recommended (Blaauw et al. 2018). We therefore chose rbacon to calculate the age depth model. Because no ${ }^{14} \mathrm{C}$-dates are available for the basal $10 \mathrm{~cm}$, ages have been extrapolated. The resulting age-depth model is shown in Figure 3: two radiocarbon dates (Poz-122314 and Poz-122367) were omitted during model simulation. 
Despite the scattering of the ${ }^{14} \mathrm{C}$-dates, our new radiocarbon datings of organic material that is not susceptible to hard water/reservoir effect indicate an Early and Middle Holocene age of the lake remnant. The Bayesian approach, adapted to scattered data, resulted in an age-depth model indicating a deposition of lake sediments between c. 9650 and $5500 \mathrm{cal} \mathrm{yr} \mathrm{BP.}$

Based on the published data in Lézine et al. (2011b) and complemented by ${ }^{14} \mathrm{C}$-dates published in Jäkel and Geyh (1982), an extended dataset of published ${ }^{14} \mathrm{C}$-dates for the Tibesti mountains was compiled. Following a modified classification scheme by Lézine et al. (2011b), the dates were assigned to the categories lacustrine, fluviatile terraces, playas, palustrine, arid and cultural and summed per millennium (Figure 6). The frequency distribution of dates of lacustrine contexts peaks during the Early Holocene, as do dates from fluviatile terraces. Considering only ${ }^{14} \mathrm{C}$-datings other than calcareous crusts, which are possibly susceptible to the hard water effect and volcanic $\mathrm{CO}_{2}$-gazing, sharpens the peak to the Early Holocene. The newly dated lacustrine sequence from the Emi Koussi caldera, which covers approximately the period 9500-5500 cal yr BP, thus fits into the palaeohydrological scheme of the Tibesti mountain range.

\subsubsection{Surface pollen sample and present vegetation}

The surface sample, a salt crust from the present-day bottom of the sub-caldera, shows a strong dominance of Ephedra distachya-type pollen, followed by high Artemisia frequencies and some Anthemis-type pollen, probably representing Pentzia (see Figure 4; Pentzia pollen belong to the Anthemis-type, cf. Vezey et al. 1994). The surface pollen spectrum thus represents the common chamaephyte steppe with the endemic species Ephedra tilhoana and Artemisia tilhoana, occurring at altitudes between $2400 \mathrm{~m}$ asl and the summit (Quézel 1959). The relationship of the endemic Ephedra tilhoana is not investigated genetically. Based on morphological traits alone, two Ephedra species are assumed to be closely related (or identical) to the Tibestian endemite: Ephedra major Host var. suggarica Maire (if not flowering/fruiting) and E. distachya L. (H. Freitag, pers. comm. 2020), both in accordance with the dominating Ephedra distachya pollen type we identified in our samples. The distribution of both taxa indicates the above-stated relation to the (altitudinal) Mediterranean and Asian steppe (see Figure 4). The affinities of the endemic Artemisia tilhoana are less clear. The global distribution and core area of Artemisia coincide, however, with the distribution of Ephedra, pointing similarly to close relations to the oro-Mediterranean and Asian steppes (e.g. Meusel and Jäger 1992).

\subsubsection{Early to Middle Holocene vegetation at the summit of Emi Koussi}

Migration of plant taxa in altitude, changes in the plant composition and substitution of the respective ecosystem are possible vegetation responses to climate fluctuations in mountains (e.g Messerli and Winiger 1992).

\subsubsection{Altitudinal plant migration}

In order to detect altitudinal migration, we define plant taxa characteristic for the lower montane belt between about 1700 and $2500 \mathrm{~m}$ asl which can be traced palynologically. Common genera with distinct pollen types are: Acacia, Rhus, Fluggea, Capparis, Boscia, Cordia, Commicarpus/Boerhavia, Grewia (tenax) and Fagonia (Maire and Monod 1950; Quézel 1959). Some of these types are present in the Early and Middle Holocene spectra: Acacia, Capparis/Cadaba and Grewia. However, in spite of the known under-representation of these pollen types (e.g. Ritchie 1994), the low frequencies point to the presence of these thorn savanna taxa close to highest altitudes, but do not indicate a distinct invasion of tropical plant taxa. The aforementioned and postulated persistence of lower temperatures during the Early and Middle Holocene are a plausible explanation of why there is no marked upward migration of tropical taxa at highest altitudes during the Holocene. 
a b c

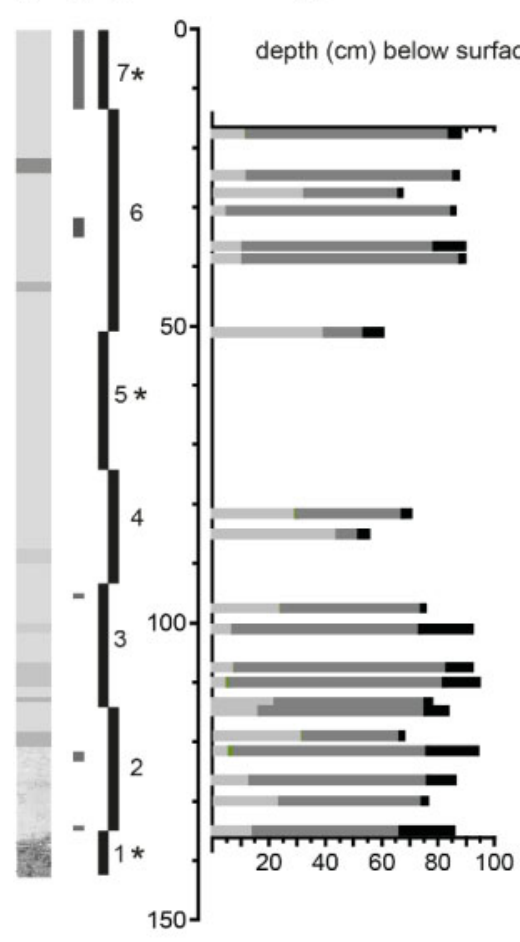

d

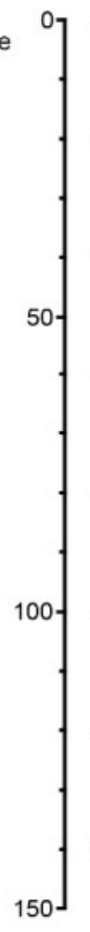

e

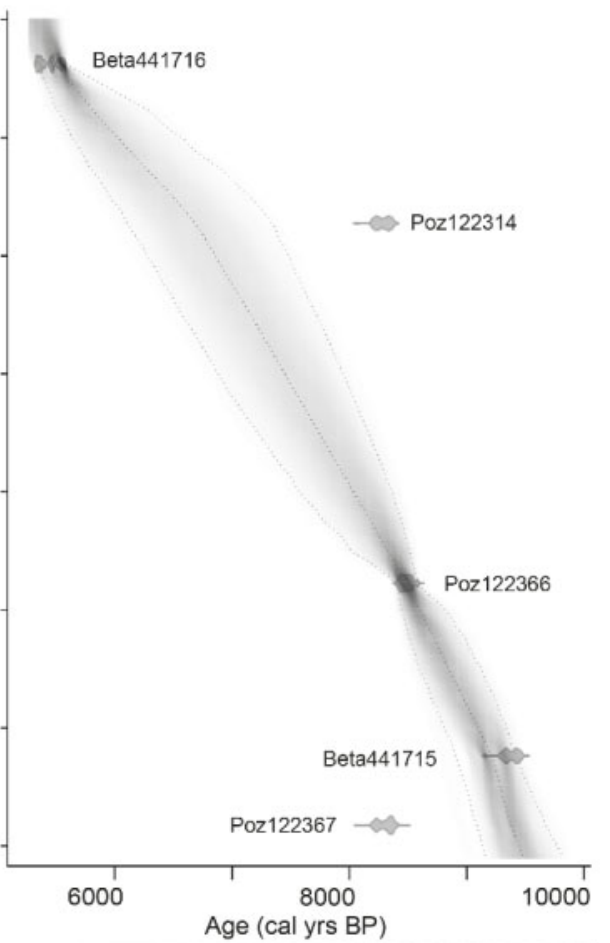

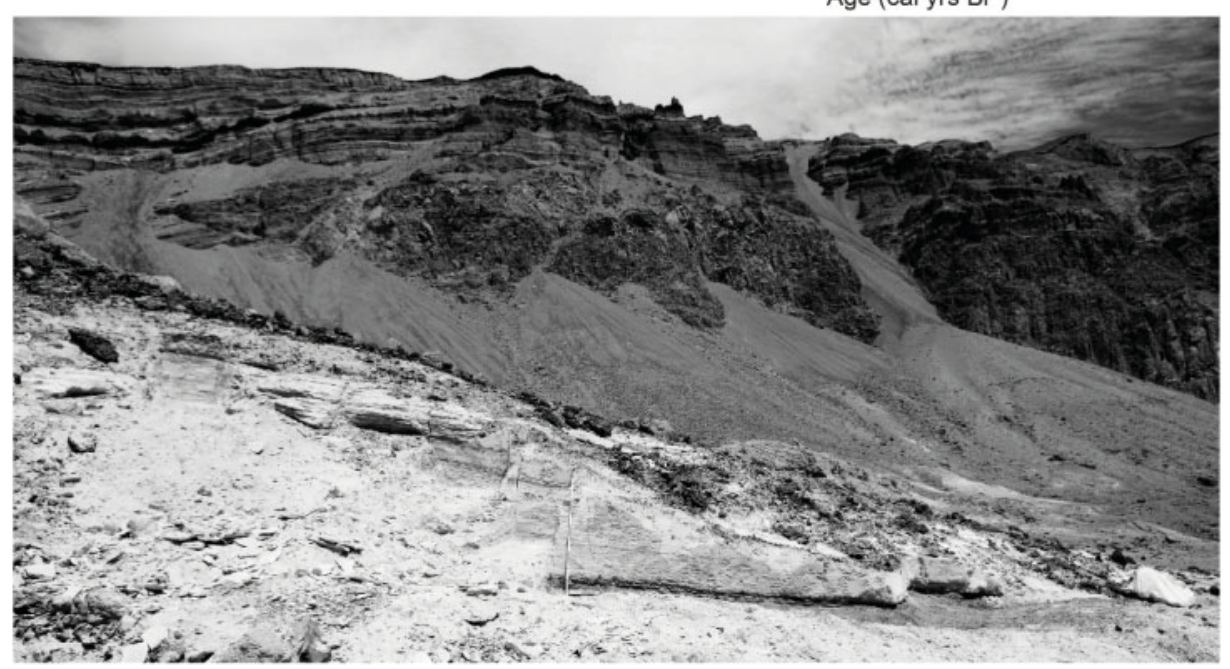

Figure 3. Stratigraphy, summary pollen diagram and age-depth plot of section W566. (a) Schematic lithography of the sampled section. (b) The grey lines indicate the position and thickness of the ${ }^{14} \mathrm{C}$-sample. (c) The black lines indicate the position and thickness of the sampled monoliths. $(*)$ sections constitute a single sample (damaged during transport).

(d) Percentage values of a few selected vegetation formations/pollen types are summed up (light grey - altitudinal steppe, dark grey - grasslands, black - ferns) and plotted against the depth, thus indicating the position of the analysed pollen samples. The same graph is plotted against age in Figure 5. The depth scale is the same in all graphs. (e) Age-depth model (simulated with rBacon). 

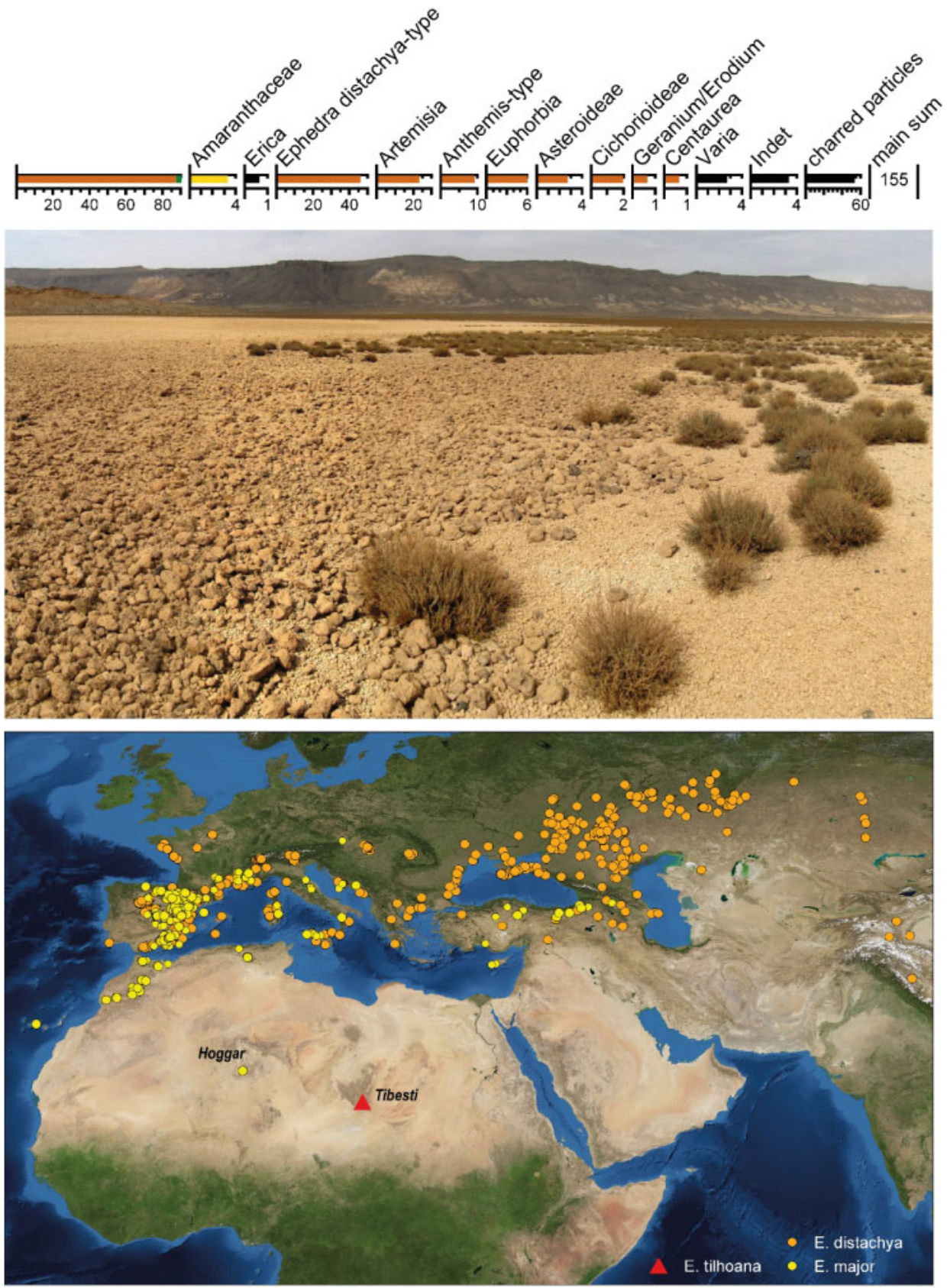

Figure 4. Above: Surface sample. The percentage values of the recorded pollen types are shown. Middle: Photo of the montane steppe at the Emi Koussi. Below: Geographic distribution of the assumed two closest relatives of the endemic Ephedra tilhoana, E. major Host and E distachya L. Only occurrences documented by plant samples are plotted (GBIF.org). 


\subsubsection{Mediterranean plant taxa migration?}

Lower temperatures in combination with increased moisture should have allowed the spread of Mediterranean tree taxa. Today, as mentioned in the introduction, Erica arborea is the only woody taxa with Mediterranean distribution in the Tibesti, occurring in a few small populations in ravines at the Emi Koussi at altitudes between 2500 and $3000 \mathrm{~m}$ asl, interpreted as relict. Genetic studies on Erica arborea indicate a range of expansion during the Pleistocene from the Eastern Africa/Arabia centre westward, pointing to its oro-African relations while colonizing the Mediterranean region and North Africa. Range fragmentation in Northern Africa resulted in the relicts in the Tibesti mountains (Bruneau de Miré and Quézel 1959; Médail and Quézel 2018) and is connected to the expansion of the Saharan desert. Genetic studies of Erica arborea imply a spread of this plant taxa during the African Humid Period (Désamoré et al. 2011). Few sporadic pollen records of Erica before $6000 \mathrm{cal}$ yr BP and higher frequencies about $6000 \mathrm{cal}$ yr BP may indicate the anticipated expansion near today's relict on the Emi Koussi. With proportions of $6.5 \%$ Erica pollen in the youngest samples of a Trou au Natron diatomite (Maley 1981), larger Erica stands are probable in the Tibesti mountains, corroborated by continuous Erica pollen input during the 6th-4th millennia BP in Lake Yoa in the plains E of the Tibesti (Kröpelin et al. 2008; Lézine et al. 2011a). Except for these Erica pollen, no Mediterranean nor Temperate plant taxa (excl. the steppic chamaephytes) are recorded in the sequence of twenty samples from the Era Kohor lake deposit. The few and low frequencies of, e.g. Pinus and Tilia, are interpreted as long-distance transport. In the palynological investigations of the scattered palaeolake sediments of the Tibesti, neither Mediterranean nor Temperate pollen types are recorded (Maley 1981), in line with palynological re-investigations of Mid-Holocene hyrax midden in the Tassili mountains, evidencing only Mediterranean trees as still present today (Thinon et al. 1996). This argument is strengthened by the lack of these elements in the charcoal spectra and only lowest pollen proportions of temperate trees, interpreted as long distance transported, in a joint pollen and charcoal investigation in the Tassili mountains (Amrani 2018). The samples from terraces as well as probably dammed up sediments near Bardai in the Tibesti revealed spectra dominated by temperate and Mediterranean pollen types (compiled in Gabriel 1977). Considering the depositional settings, a re-working of older, Pleistocene sediments bearing Mediterranean and Temperate pollen (see Introduction, Rossignol and Maley 1969) can explain these spectra. Relying on the first sequence from a palaeolake, and underpinned by the above-mentioned investigations (Maley 1981; Thinon et al. 1996) and our own ongoing analyses of the Early to Middle Holocene sediments of Lake Yoa (Dinies et al. 2019), an expansion of Mediterranean woodlands in the Tibesti can be ruled out, though. Two circumstances or a combination of both can explain the lack of Mediterranean woody taxa. First, the Early and Middle Holocene climatic conditions at high altitudes in the Tibesti mountains were unsuitable (too dry). Second, a migration of Mediterranean (woody) taxa from the source area was not possible during the Holocene, because aridity persisted in the plains north of the Tibesti, and relicts that could expand were not present in the mountains, with the exception of the present Erica-relict. The few records of Mediterranean taxa with low frequencies in the Fezzan in the area northwest of the Tibesti mountains and the Central Saharan plains corroborate the latter explanation (e.g. Mercuri 2008; Mercuri et al. 1998; Schulz 1991; Trevisan et al. 1998).

\subsubsection{Shift in the plant composition}

The actual pollen spectrum is dominated by the chamaephytes Ephedra and Artemisia. In contrast Poaceae prevail in the Early and Middle Holocene spectra, together with at times high Artemisia proportions and high fern proportions in the lower part of the sequence. This distinct difference between the basal pollen spectra of the palaeolake and the surface sample, though biased by the different type of samples, evidences that at about 9500 cal yrs BP more humid conditions than today were already established at high altitudes in the Tibesti. 

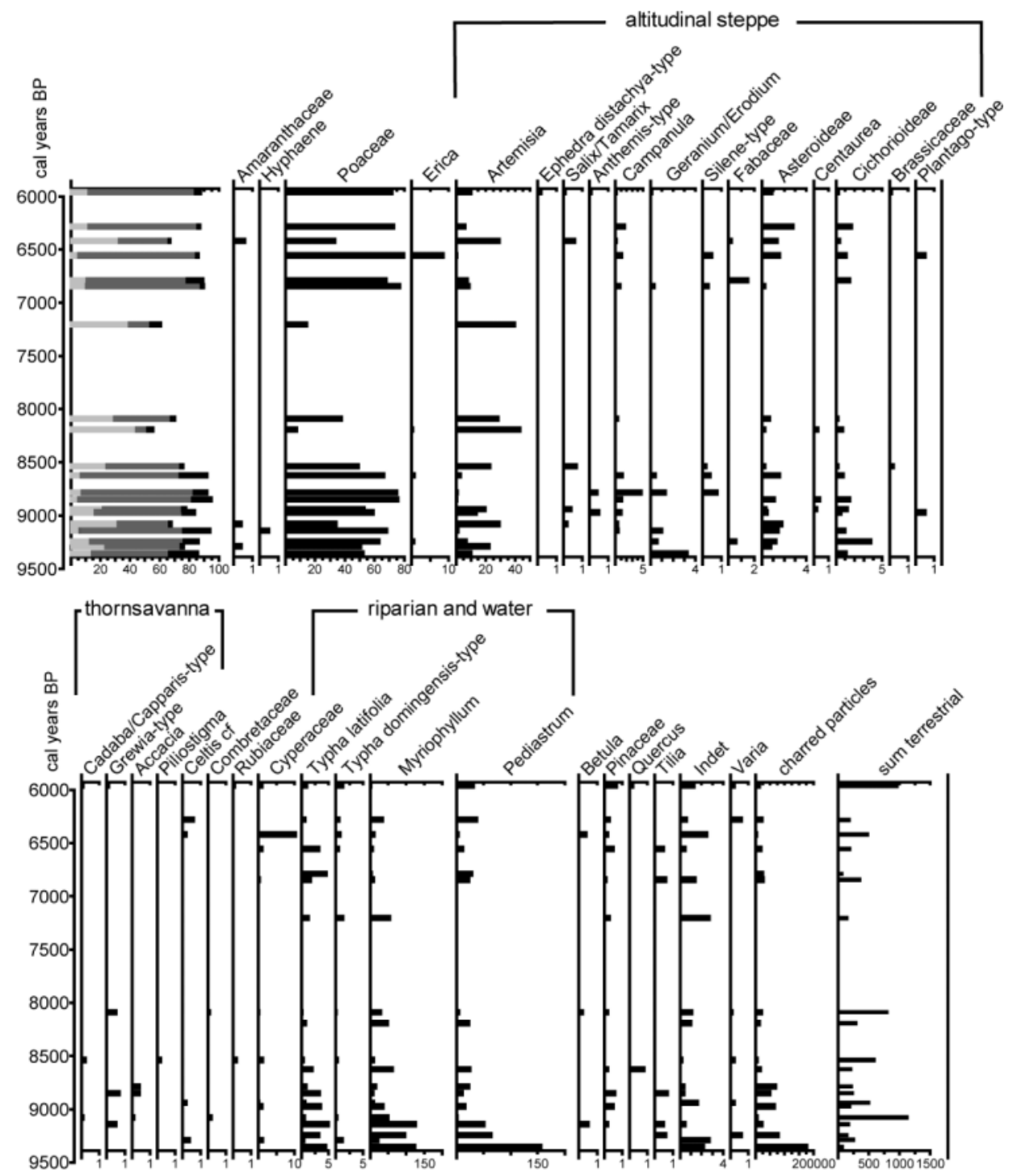

Figure 5. Pollen diagram of section W566. Percentages of pollen types plotted versus age (cal yr BP). Only pollen types present in more than one sample are shown. The first summary graph shows the fluctuations of: light grey altitudinal steppe, grey - grasslands, black - ferns. The pollen types are grouped according to their ecology.

Ferns still occur today in the Tibesti mountains, however only very rarely and in specific habitats such as shaded fissures and fumerolles at high altitudes, thus in humidity-advantaged localities (Maire and Monod 1950; Quézel 1958). The high fern proportions during the Early and Middle Holocene therefore point to increased humidity, most probably especially to an extended wetter period that fostered their growth, as indicated in the Lake Yoa record in the southeastern foreland (Lézine et al. 2011a). Some scattered palynological investigations of palaeolake sediments in the Tibesti revealed high fern spore proportions which are similarly interpreted as mirroring wetter conditions (Maley 1981). Ferns were also abundantly recorded in an Early 
Holocene lacustrine deposit in the present-day desert of Yemen (Lézine et al. 2007). In an analysis of surface samples throughout the African continent, higher fern proportions are assigned to mean annual precipitation amounts $>100 \mathrm{~mm}$, peaking about $1200 \mathrm{~mm}$, corroborating the connection to increased humidity (Gajewski et al. 2002). The simultaneously high Poaceae frequencies in our Era Kohor sequence fit into this assumption. Following the interpretation of shifts between Artemisia (and Amaranthaceae) versus Poaceae by El Moslimany (1987, 1990), higher grass proportions indicate an increase in humidity during the growing season of grasses. The highest altitudinal pollen spectra in the Early and Middle Holocene thus show a distinct switch in plant composition, indicating increased humidity, probably encompassing a large part of the year. However, despite the marked shift in plant taxa composition, the steppe ecosystem persisted. This is corroborated by the records of additional plant taxa typical for the altitudinal steppes such as Campanula filicaulis or C. bordesiana, included in the Campanula type, or e.g. Erodium malacoides included in Geranium/Erodium pollen type.

\subsubsection{Shallow water and riparian vegetation}

Myriophyllum-type includes the tropical genus Laurembergia and Myriophyllum. Due to the temperature considerations, an occurrence of Myriophyllum is more probable. Myriophyllum spicatum occur on the Djebel Marra at elevations between 1160 and $2450 \mathrm{~m}$ asl (Wickens 1967), commonly growing in shallow water habitats (Hegi 1975). The continuous record of Myriophyllum-type pollen indicates the persistence of a shallow water zone throughout the Early and Middle Holocene. A continuous riparian belt is similarly corroborated by the continuous records of Typha domingensis and Typha latifolia (Quézel 1958). While Myriophyllum spicatum and Typha species tolerate brackish water, at least the recent genus Pediastrum is mainly restricted to fresh-water habitats, and is very rarely recorded in brackish biotopes (Hegi 1975; Komarek and Jankovska 2001). However, freshwater influxes into a brackish lake may as well explain the occurrence of Pediastrum. The riparian and water vegetation thus indicate a shallow and freshwater-to-brackish lake throughout the Holocene, at least at the position of the sampled lake remnants on the slopes of the Era Kohor crater, some $145 \mathrm{~m}$ above the caldera floor.

\subsubsection{Early and Middle Holocene high altitude climate settings derived from montane vegetation}

Ferns, grasses and the records of some tropical taxa at highest altitudes suggest humid conditions. In contrast, higher Artemisia proportions can be connected to an increase in aridity. Though the genus Artemisia is characterized by a wide range of bio-climatic requirements, the opposed progression of grasses and Artemisia points to the validity of this assumption for the Tibesti (e.g. Langgut et al. 2011; Lézine et al. 2011a; Subally and Quézel 2002). Ephedra distachya-type is another indicator for aridity: low proportions of Ephedra distachya-type in the Middle Holocene spectra (cf. also Maley 1981) as compared to its highest frequencies in the surface sample, as well as the general bioclimatic interpretation, evidence its positive correlation with aridity (Gajewski et al. 2002; Qin et al. 2015).

Based on these assumptions, a humidity progression including ferns and Poaceae versus Artemisia and Ephedra distachya-type may be postulated (Figure 5). Highly fluctuating, but basically more humid conditions characterize the period between 9500 and 8500 cal yrs BP, while three samples about $8000 \mathrm{cal}$ yr BP point to decreased humidity. These more arid conditions may be concomitant with the arid '8.2' identified elsewhere in Africa event (e.g. Gasse 2000). Whether more arid conditions prevailed until about $7000 \mathrm{cal} \mathrm{yr} \mathrm{BP}$ or whether results are biased by relying on only one sample remains an open question. During the period from about 7000 to 6000 cal yrs BP humidity increased again, however tentatively less distinctly than during the Early Holocene. Interestingly, the humidity index is roughly in line with the frequency distribution of the hydrological indicators: with the peak in lacustrine dated deposits, the humidity index, 


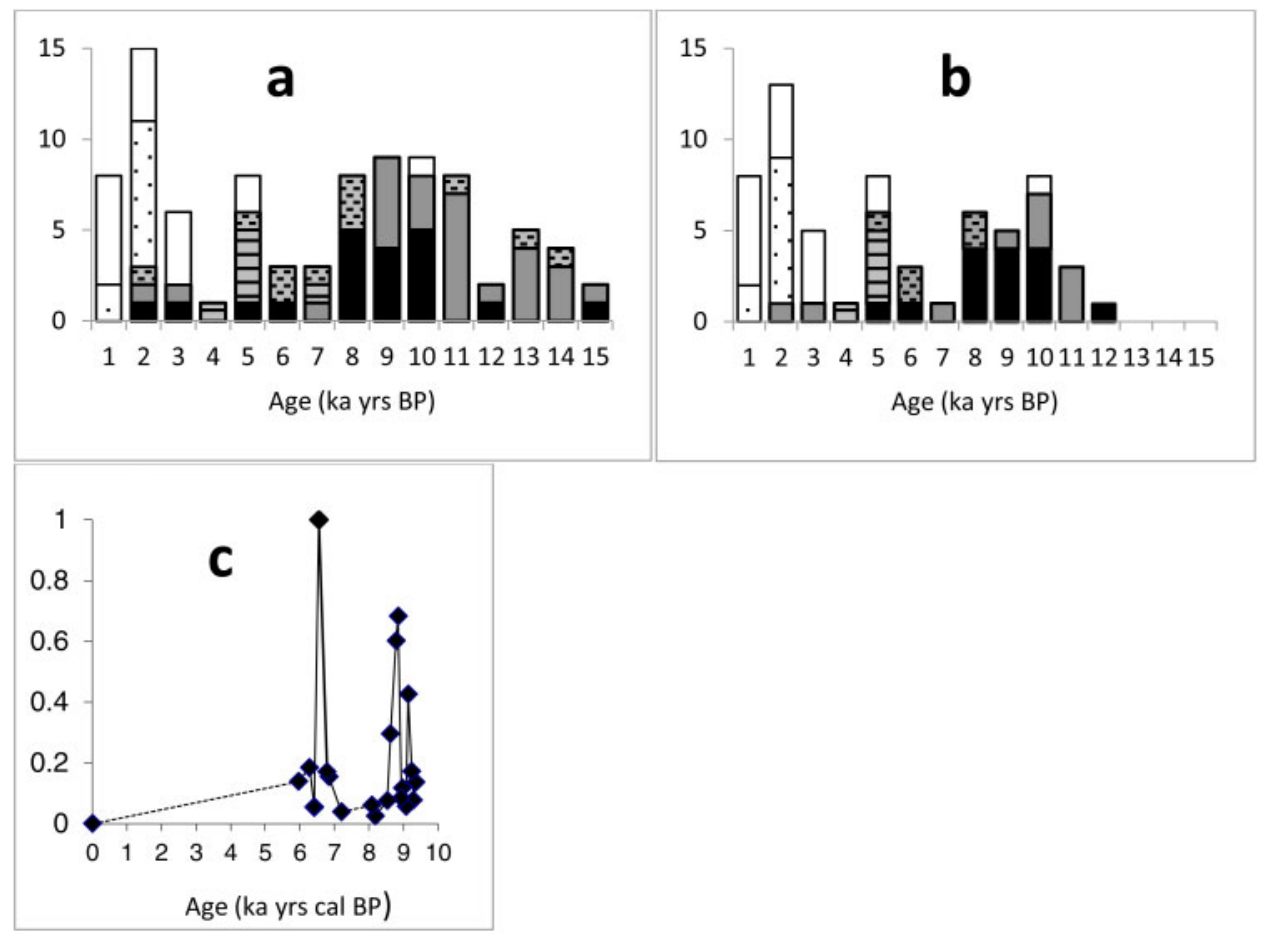

Figure 6. Humidity index and frequency distribution of hydrological indicators by age: (a) Frequency distribution of

${ }^{14} \mathrm{C}$-dates from different geomorphological and archaeological formations including all ${ }^{14} \mathrm{C}$-datation, (b) excluding the calcareous crusts. Black = lacustrine sediments, grey = fluviatile terraces, grey/dashes = palustrine sediments, grey/lines $=$ playa sediments, white/points $=$ arid settings, white $=$ cultural layers (c) Humidity index: The proportions of Poaceae and ferns versus Artemisia and Ephedra distchya-type, scaled to 1, are plotted against age. The surface sample mirroring the present climatic conditions is shown as a separate point.

though distinctly fluctuating, reaches high values during the 9th and 8th millennia BP. Both proxies show a depression during the 7 th millennium, pointing to reduced humidity, while in the 6 th millennium wetter conditions were established again, with a maximum of the humidity index and (augmented) lacustrine and fluviatile sedimentation.

As to precipitation estimates, the major issues are the distinct shift in vegetation composition and the persistence of the steppe ecosystem at high altitudes. To assess rainfall amounts, the bioclimatic requirements of Mediterranean, North African steppes as well as altitudinal, continental dry steppes dominated by dwarf shrubs may be considered. The precipitation marge for the Mediterranean, North African steppes varies between 100 and 400 mm/a (Le Houérou 1995, 2001). To get a notion of the altitudinal factor, altitudinal, continental dry steppes dominated by Artemisia in SW Asia (Iran) may additionally be considered an equivalent. In an altitudinal vegetation-pollen-rain transect in SW Iran, rainfall amounts of about 100-300 mm/a are assigned to Artemisia-dominated steppes at altitudes about $800-1500 \mathrm{~m}$ asl mirrored by high Artemisia pollen proportions. The subsequent, treeless montane and alpine grass-dominated belt at $>1500$ $\mathrm{m}$ asl, characterized in the pollen spectra by high Poaceae frequencies, profits from orographic rainfall increase of about 300-500 mm/a (Dehghani et al. 2017). Because of the recurrent high Artemisia proportions in the W566 sequence, underpinned by high Artemisia frequencies in a sample from another Early Holocene lake remnant of Emi Koussi (Maley 1981), a range near the threshold between Artemisia - Poaceae dominated zones may be assumed at about 300-400 mm/a, 
and up to $500 \mathrm{~mm} / \mathrm{a}$ for the grass-dominated sections. By applying the actual adiabatic lapse rate (roughly $50 \mathrm{~mm}$ per $1000 \mathrm{~m}$ ), rainfall similarly would amount to $370-540 \mathrm{~mm} / \mathrm{a}$. Precipitation estimates for the Middle Holocene in the Ounianga Basin southwest of the Tibesti massif based on transfer functions resulted in 250-420 mm/a (Kröpelin et al. 2008; Lézine et al. 2011a). At present $<5 \mathrm{~mm} / \mathrm{a}$ are indicated for the Ounianga Basin and $80-150 \mathrm{~mm} / \mathrm{a}$ are estimated for the high altitudes of the Emi Koussi. Indications concerning temperature fluctuations are less distinct. The lack of a mass expansion of tropical trees points to (persisting) low temperatures. Diatom spectra of the Emi Koussi similarly speak in favour of persisting low or even lower temperatures at the beginning of lake formation (Messerli 1972). Both assumptions are in line with continental scale pollen-based climate reconstructions at 6000 years BP for the region Northern Chad and Southern Libya, indicating an increase of precipitation $>200 \mathrm{~mm} / \mathrm{a}$ with an inconsistent pattern for temperature, however also in parts indicating a temperature decrease, resulting from an increased monsoon (Bartlein et al. 2011).

\subsection{SUMMARY AND CONCLUSIONS}

The age-depth model of a lake remnant based on ${ }^{14} \mathrm{C}$-dates of charred plant material and the investigation of a sequence of 20 pollen samples from this palaeolake in the Emi Koussi crater, SE Tibesti mountains, allow inferences on some pending issues:

There is no palynological evidence of an Early and Middle Holocene expansion of Mediterranean (and Temperate) plant taxa in the Tibesti mountains (except for the relict Erica). For the first time, a palynological sequence has been analysed, improving the previously erratic data basis of single pollen samples. None of the newly investigated pollen samples shows higher frequencies of Mediterranean or Temperate taxa. This is in line with the single-sample palynological investigation of lake remnants in the Trou au Natron and the SE Tibesti (Emi Koussi, Mouskorbé, Tarso Yega, Maley 1981). Neither a re-migration of Mediterranean tree taxa from the north, nor an expansion from possible refuge habitats was thus possible during the Holocene. A rather poorly developed palaeohydrological network reconstructed for the surroundings of the Tibesti (HydroSHEDS; https://www.hydrosheds.org/) seems to corroborate its more isolated situation when compared to the Hoggar mountains in the NW, where there are more Mediterranean tree relicts (Cupressus dupreziana, Olea europaea subsp. laperrinei e.g. Quézel 1965). An exception is the spread of Erica arborea at the end of the African Humid Period in the Tibesti. However, relict stands of Erica continue to exist today at the Emi Koussi. Similarly, Erica arborea may have outlasted the last Glacial and expanded under favourable conditions about 6000 years ago.

Lake formation at the highest altitudes of the Tibesti and the surrounding plains is synchronous. The radiocarbon-dated charred plant particles from the diatomite W566 of the Era Kohor caldera clearly indicate its Holocene age. The lake formation at highest altitudes thus fits into the main phase of lake and terraces formation in the Tibesti mountains, as shown by the frequency distribution of ${ }^{14} \mathrm{C}$-dates of these geomorphological formations - and is synchronous to the well-defined palaeolake phase in the Saharan plains (e.g. Cremaschi and Zerboni 2009; Hoelzmann et al. 1998; Holmes and Hoelzmann 2017; Kuper and Kröpelin 2006; Lézine et al. 2011b; Lécuyer et al. 2016; van Neer et al. 2020). This does not exclude an increase in humidity pre-dating the formation of lakes: the high Poaceae frequencies in the basal pollen samples of the Emi Koussi sequence indicate wetter conditions already at the beginning of lake formation.

Distinct changes in plant composition with the persistence of the montane steppe ecosystem indicate increased humidity and probably continued low temperatures. Palynological investigations on the W566 lake sediments in the Era Kohor sub-caldera document the persistence of a steppe at high altitudes. Changed climatic conditions, however, are indicated by high Poaceae and fern frequencies and strongly fluctuating Artemisia proportions during the African Humid period versus strongly dominating Ephedra distachya-type proportions, together with Artemisia, 
reflecting the present vegetation. The resultant calculated humidity index indicates wetter conditions during the Early Holocene, more arid conditions about 8200-8000 cal yr BP presumably lasting until about $7000 \mathrm{cal} \mathrm{yr} \mathrm{BP}$, and an increase in humidity during the 6th millennium.

In analogy to Mediterranean and Asian chamaephyte steppes, a three- to fivefold increase in precipitation (c. 400-550 mm/a) may be estimated. The lack of a mass expansion of tropical taxa at high altitudes points to persisting low temperatures during the African Humid period. Holocene climate fluctuations thus impacted the surrounding plains more strongly, triggering large-scale ecosystem changes. High altitudinal ecosystems in the Tibesti were less affected, probably in consequence of the persisting specific climatic conditions (low temperatures) that still prevail today due to the singular geographic position of the Tibesti between the Mediterranean and the tropical climate regimes.

With its additional habitats such as riparian vegetation and additional grass-dominated plant formations at highest altitudes, the mountain ranges of the Tibesti may have attracted humans and wild animal populations. Due to the more stable conditions than in the plains, the Tibesti has acted (and acts) as a refuge, e.g. for Ephedra during the African Humid period or today for Erica relict stands - which of course holds true for humans and animals as well.

\subsection{ACKNOWLEDGEMENTS}

This study is supported by a grant from the DFG priority program SPP 1234 'Entangled Africa'. DEM data were provided by the DLR (Deutsches Zentrum für Luft- und Raumfahrt/German Aerospace Center). Fieldwork was supported by DFG project 57444011-SFB806. We are grateful to Dr. Baba Mallaye, Director of the Centre National de la Recherche pour le Développement (CNRD) in N'Djaména, for his comprehensive support of the missions. We also thank our team members Jan Kuper and Mahadi Chaha for their help with the sampling. We thank an anonymous reviewer and Jean Maley for their most fruitful reviews and suggestions which most significantly improved the manuscript.

\section{REFERENCES}

Alimen, H., Beucher, F. and Lhote, H., 1968, Les gisements néolithiques de Tan-Tartait et d'I-nItinen Tassili-n-Ajjer (Sahara Central). Bulletin de la Société préhistorique francaise, $\mathbf{L X V}$, pp. 421-458, 10.3406/bspf.1968.4160.

Amrani, S., 2018, The Holocene flora and vegetation of Ti-n Hanakaten (Tassili n'Ajjer, Algerian Sahara). Plants and People in the African Past edited by Mercuri, A., d'Andrea, A., Fornaciari, R. and Höhn, A., Springer, pp. 123-145.

Ball, P., White, N., Masoud, A., Nixon, S., Hoggard, M., Maclennan, J., Stuart, F., Oppenheimer, C. and Kröpelin, S., 2019, Quantifying asthenospheric and lithospheric controls on ma?c magmatism across North Africa. Geochemistry, Geophysics, Geosystems, 20, pp. 3520-3555, 10.1029/2019GC008303.

Bartlein, P. J., Harrison, S. P., Brewer, S., Connor, S., Davis, B. S. A., Gajewski, K., Guiot, J., Harrison-Prentice, T. I., Henderson, A., Peyron, O., Prentice, J. C., Scholze, M., Seppä, H., Shuman, B., Sugita, S., Thompson, R. S., Viau, A. E., Williams, J. and Wu, H., 2011, Pollen-based continental climate reconstructions at 6 and $21 \mathrm{ka}$ : A global synthesis. Climate Dynamics, 37, pp. 775-802, 10.1007/s00382-010-0904-1.

Baumhauer, R., 2004, Some new insights into palaeoenvironmental dynamics and Holocene landscape evolution in the Nigrian Central Sahara (Ténéré, Erg of Ténéré, Erg of Fachi-Bilma). Zentralblatt für Geologie und Paläontologie, 1, pp. 387-403, 10.1127/zgpI/2014/0387-0403. 
Blaauw, M. and Christen, J.A., 2011, Flexible paleoclimate age-depth models using an autogressive gamma process. Bayesian Analysis 6(3), pp. 457-474, 10.1214/ba/1339616472.

Blaauw, M., Christen, J. A., Bennett, K. D. and Reimer, P. J., 2018, Double the dates and go for Bayes - Impacts of model choice, dating density and quality on chronologies. Quaternary Science Reviews, 188, pp. 58-66, 10.1016/j.quascirev.2018.03.032.

Bonnefille, R. and Riollet, G., 1980, Pollens des Savanes d'Afrique Orientale. Paris : CNRS.

Braconnot, P., Joussaume, S., Marti, O., and de Noblet, N., 1999, Synergistic feedbacks from ocean and vegetation on the African monsoon response to mid-Holocene insolation. Geophysical Research Letters, 26, pp. 2481-2484, 10.1029/1999GL006047.

Braconnot, P., Otto-Bliesner, B., Harrison, S., Joussaume, S., Peterchmitt, J.-Y., Abe-Ouchi, A., Crucifix, M., Driesschaert, E., Fichefet, Th., Hewitt, C. D., Kageyama, M., Kitoh, A., Loutre, M.-F., Marti, O., Merkel, U., Ramstein, G., Valdes, P., Weber, L., Yu, Y. and Zhao, Y., 2007, Results of PMIP2 coupled simulations of the Mid-Holocene and Last Glacial Maximum Part 2: feedbacks with emphasis on the location of the ITCZ and mid- and high latitudes heat budge. Climate of the Past 3(2), 279-296, 10.5194/cp-3-279-2007.

Brown, T. A., Farwell, G., Grootes, P. and Schmidt, F., 1992, Radiocarbon AMS dating of pollen extracted from peat samples. Radiocarbon 43(3), pp. 550-556, 10.1017/S00338222000 63815 .

Bruneau de Miré, P. and Quézel, P., 1959, Sur la présence de la bruyère en arbre (Erica arborea L.) sur les sommets de l'emi Koussi (massif du Tibesti). Compte rendu sommaire des séances de la Société de biogéographie, 36, pp. 66-70.

Chester, P. and Prior, C., 2004, An AMS ${ }^{14}$ C pollen-dated sediment and pollen sequence from the Late Holocene, southern coastal Hawke's Bay, New Zealand. Radiocarbon 46(2), pp. 721-731, $10.1017 / \mathrm{S} 0033822200035761$.

Claussen, M. and Gayler, V., 1997, The greening of the Sahara during the mid-Holocene: results of an interactive atmosphere-biome model. Global Ecology and Biogeography Letters, 6, pp. 369-377, 10.2307/2997337.

Claussen, M., Kubatzki, C., Brovkin, V., Ganopolski, A., Hoelzmann, P. and Pachur, H. J., 1999, Simulation of an abrupt change in Saharan vegetation in the mid-Holocene. Geophysical Research Letters, 26, pp. 2037-2040, 10.1029/1999GL900494.

Cremaschi, M. and Zerboni, A., 2009, Early to Middle Holocene landscape exploitation in a drying environment: Two case studies compared from the central Sahara (SW Fezzan, Libya). Comptes Rendus - Geoscience, 341, pp. 689-702, 10.1016/j.crte.2009.05.001.

Dallmeyer, A., Claussen, M., Lorenz, S. J. and Shanahan, T., 2020, The end of the African humid period as seen by a transient comprehensive Earth system model simulation of the last 8000 years. Climate of the Past, 16, pp. 117-140, 10.5194/cp-16-117-2020.

Dehghani, M., Djamali, M., Gandouin, E. and Akhani, H., 2017, A pollen rain-vegetation study along a $3600 \mathrm{~m}$ mountain-desert transect in the Irano-Turanain region; implications for the reliability of some pollen ratios as moisture indicators. Review of Palaeobotany and Palynology, 247, pp. 133-148, 10.1016/j.revpalbo.2017.08.004.

Désamoré, A., Laenen, B., Devos, N., Popp, M., Gonzalez-Mancebo, J., Carine, M. and Vanderpoorten, A., 2011, Out of Africa: north-westwards Pleistocene expansions of the heather Erica arborea. Journal of Biogeography 38, 164-176, 10.1111/j.1365-2699.2010.02387.x.

Deniel, C., Vincent, P. M., Beauvilain, A. and Gourgaud, A., 2015, The Cenozoic volcanic province of Tibesti (Sahara of Chad): major units, chronology, and structural features. Bulletin of Volcanology 77(74), pp. 1-21, 10.1007/s00445-015-0955-6.

Dinies, M., Hoelzmann, P., Karls, J., Melles, M., Wennrich, V., Claussen, M., Neef, R. and Kröpelin, S., 2019, Continental records for the 'African Humid Period': lake sediment archives from the Ounianga Basin and the Tibesti Mountains, N Chad. Abstract, INQUA20 ${ }^{\text {th }}$ Congress, O-3016. 
Eisele, G., Haas, K. and Liner, S., 1994, Methode zur Aufbereitung fossilen Pollens aus minerogenen Sedimenten. Göttinger Geographische Abhandlungen, 95, pp. 165-166.

El-Ghazali, G., 1991, A study on the pollen flora of Sudan. Review of Palaeobotany and Palynology 76(2-4), pp. 99-345, 10.1016/0034-6667(93)90077-8.

El-Moslimany, A.P., 1987, The Late Pleistocene climates of the lake Zeribar region (Kurdistan, Western Iran) deduced from the ecology and pollen production of non-arboreal vegetation. Vegetatio, 72(3), pp. 131-139.

El-Moslimany, A.P., 1990, Ecological significance of common non-arboreal pollen: examples from drylands of the Middle East. Review of Palaeobotany and Palynology 64, pp. 343-350, $10.1016 / 0034-6667(90) 90150-\mathrm{H}$.

Faegri, K. and Iversen, J., 1989, Textbook of Pollen Analysis. Chichester: John Wiley \& Sons Ltd.

Faure, H., 1969, Lacs quaternaires du Sahara. Mitteilungen des Internationalen Vereins für Limnologie, 17, pp. 131-146, 10.1080/05384680.1969.11903878.

Gabriel, B., 1977, Zum ökologischen Wandel im Neolithikum der östlichen Zentralsahara. Berliner Geographische Abhandlungen, 27, pp. 1-111.

Gajewski, K., Lézine, A.-M., Vincens, A., Delestan, A., Sawada, M. and the African Pollen Database, 2002, Modern climate-vegetation-pollen relations in Africa and adjacent areas. Quaternary Science Reviews, 21, pp. 1611-1631, 10.1016/S0277-3791(01)00152-4.

Gasse, F., 2000, Hydrological changes in the African tropics since the Last Glacial Maximum. Quaternary Science Reviews, 19, pp. 189-211, 10.1016/S0277-3791(99)00061-X.

Gavrilovic, D., 1969, Klimatabellen für das Tibesti-Gebirge. Arbeitsberichte aus der Forschungsstation Bardai/Tibesti 8 edited by J. Höevermann, G. Jensch, H. Valentin, W. Woehlke and H. Hagedorn, H., pp. 47-48.

Gourgaud, A. and Vincent, P., 2004, Petrology of two continental alkaline intraplate series at Emi Koussi volcano, Tibesti, Chad. Journal of volcanology and geothermal research, 129(4), pp. 261-290, 10.1016/S0377-0273(03)00277-4.

Grimm, E., 2020, Tilia version 2.6.1 [software]. https://www.tiliait.com/

Haynes, C., Eyles, C., Pavlish, L., Ritchie, J. and Rybak, M., 1989, Holocene palaeoecology of the Eastern Sahara; Selima oasis. Quaternary Science Reviews, 8, pp. 109-136, 10.1016/02773791(89)90001-2.

Hegi, G., 1975, Illustrierte Flora von Mitteleuropa. V/2, Berlin-Hamburg: Paul Parey.

Hély, C. and Lézine, A.-M., 2014, Holocene changes in African vegetation: Tradeoff between climate and water availability. Climate of the Past, 10, pp. 681-686, 10.5194/cp-10681-2014.

Hoelzmann, P., Jolly, D., Harrison, S.P., Laarif, F., Bonnefille, R. and Pachur, H.J., 1998, MidHolocene land-surface conditions in northern Africa and the Arabian peninsula: A data set for the analysis of biogeophysical feedbacks in the climate system. Global Biogeochemical Cycles, 12(1), pp. 35-51, 10.1029/97GB02733.

Holmes, J. and Hoelzmann, P., 2017, The Late Pleistocene-Holocene African Humid Period as Evident in Lakes. The Oxford Research Encyclopedia of Climate Science; Regional and Local Climates, 10.1093/acrefore/9780190228620.013.531.

Jäkel, D. and Geyh, M.A., 1982, ${ }^{14}$ C-Daten aus dem Gebiet der Sahara, hervorgegangen aus Arbeiten der Forschungsstation Bardai und des Niedersächsischen Landesamtes für Bodenforschung in Hannover. Berliner Geographische Abhandlungen, 32, pp. 143-166.

Jahns, S., 1995, A Holocene pollen diagram from El Atrun, northern Sudan. Vegetation History and Archaeobotany, 4, pp. 23-30, 10.1007/BF00198612.

Knippertz, P., 2005, Tropical-extratropical interactions associated with an Atlantic tropical plume and subtropical jet streak. Monthly Weather Review, 133, pp. 2759-2776, 10.1175/MWR2999.1. 
Köppen, W., 1918, Klassifikation der Klimate nach Temperatur, Niederschlag and Jahreslauf. Petermanns Geographische Mitteilungen, 64, pp.193-203.

Komarek, J. and Jankovska, V., 2001, Review of the green algal genus Pediastrum; Implication for pollen-analytical research., Berlin, Stuttgart: Cramer.

Krinner, G., Lézine, A.-M., Braconnot, P., Ramstein, G., Grenier, C. and Gouttevin, I., 2012, Strong timescale-dependent feedbacks on the North African Holocene climate by lakes and wetlands. Geophysical Research Letters, 39(7), L07701, 10.1029/2012GL050992.

Kröpelin, S., Verschuren, D., Lézine, A.-M., Eggermont, H., Cocquyt, C., Francus, P., Cazet, J.-P., Fagot, M., Rumes, B., Russell, J., Darius, F., Conley, D., Schuster, M., Suchodoletz, H. and Engstrom, D., 2008, Climate-driven ecosystem succession in the Sahara: The past 6000 years. Science, 320, pp. 765-768, 10.1126/science.1154913.

Kröpelin, S., Dinies, M., Sylvestre, F. and Hoelzmann, F., 2016, Crater palaeolakes in the Tibesti mountains (Central Sahara, North Chad) - New insights into past Saharan climates. Geophysical Research Abstracts, 18, EGU2016-6557.

Kuper, R. and Kröpelin, S., 2006, Climate-Controlled Holocene Occupation in the Sahara: Motor of Africa's Evolution. Science, 313, pp. 803-807, 10.1126/science.1130989.

Kutschera, W., 2016, Accelerator mass spectrometry: state of the art and perspectives.Advances in Physics $\mathbf{X}(1,4)$, pp. 62-65.

Kutzbach, J. E., 1981, Monsoon climate of the early Holocene: Climate experiment with the Earth's orbital parameters for 9000 years ago. Science, 214(4516), pp. 59-61, 10.1126/science.214.4516.59.

Kutzbach, J. E. and Liu, Z., 1997, Response of the African Monsoon to Orbital Forcing and Ocean Feedbacks in the Middle Holocene. Science, 278(5337), pp. 440-443, 10.1126/science.278.5337.440.

Langgut, D., Almogi-Labin, A., Bar-Matthews, M. and Weinstein-Evron, M., 2011, Vegetation and climate changes in the South Eastern Mediterranean during the Last Glacial-Interglacial cycle (86 ka): new marine pollen record. Quaternary Science Reviews, 30, pp. 3960-3972, 10.1016/j.quascirev.2011.10.016.

Lécuyer, C, Lézine, A.-M., Fourel, F., Gasse, F., Sylvestre, F., Pailles, C., Grenier, C., Travi, Y. and Barral, A., 2016, In-Atei palaeolake documents past environmental changes in central Sahara at the time of the "Green Sahara": Charcoal, carbon isotope and diatom records. Palaeogeography, Palaeoclimatology, Palaeoecology, 441, pp. 834-44, 10.1016/j.palaeo.2015.10.032.

Le Houérou, H. N., 1995, Bioclimatologie et biogéographie des steppes arides du nord de l'Afrique. Options méditerranéennes, 10, pp. 1-396.

Le Houérou, H. N., 2001, Biogeography of the arid steppeland north of the Sahara. Journal of Arid Environments, 48, pp. 103-128, 10.1006/jare.2000.0679.

Le Houérou, H. N., 2009, Bioclimatology and biogeography of Africa. Berlin, Heidelberg: Springer.

Lézine, A.-M., Tiercelin, J.-J., Robert, C., Saliège, J.-F., Cleuziou, S., Inzian, M.-L. and Braemer, F., 2007, Centennial to millennial-scale variability of the Indian monsoon during the early Holocene from a sediment, pollen and isotope record from the desert of Yemen. Palaeogeography, Palaeoclimatology, Palaeoecology, 243(3-4), pp. 235-249, 10.1016/j.palaeo.2006.05.019.

Lézine, A.-M., Zheng, W., Braconnot, P. and Krinner, G., 2011a, Late Holocene plant and climate evolution at Lake Yoa, northern Chad: pollen data and climate simulations. Climate of the Past, 7, pp. 1351-1362, 10.5194/cp-7-1351-2011.

Lézine A.-M., Hély, C., Grenier, C., Braconnot P., Krinner G., 2011b, Sahara and Sahel vulnerability to climate changes, lessons from Holocene hydrological data. Quaternary Science Reviews, 30, pp. 3001-3012, 10.1016/j.quascirev.2011.07.006.

Lézine, A.-M., 2017, Vegetation at the Time of the African Humid Period. Oxford University Press, 10.1093/acrefore/9780190228620.013.530. 
Maire, R., 1935, Contribution à l'étude de la flore du Tibesti. Mémoires de l'Académie des Sciences de l'institut de France, 62, pp. 1-39.

Maire, R. and Monod, T., 1950, Étude sur la flore et la végétation du Tibesti. Mémoire de lIinstitut francais d'Afrique noire, 8, pp. 1-140.

Maley, J., 1981, Etudes palynologiques dans le bassin du Tchad et paléoclimatologie de l'Afrique nord-tropicale de 30000 ans à l'époque actuelle. Travaux et Documents de l'ORSTOM 129, pp. $1-586$.

Maley, J., 2000, Last Glacial Maximum lacustrine and fluviatile Formations in the Tibesti and other Saharan mountains, and large-scale climatic teleconnections linked to the activity of the Subtropical Jet Stream. Global and Planetary Change, 26, pp. 121-136, 10.1016/S09218181(00)00039-4.

Médail, F. and Quézel, P., 2018, Biogéographie de la flore du Sahara: Une biodiversité en situation extrême. Marseille : IRD Éditions, Conservatoire et Jardin botaniques de la Ville de Genève.

Mercuri, A., Grandi, G., Mariotti Lippi, M. and Cremaschi, M., 1998, New pollen data from the Uan Muhuggiag rockshelter (Libyan Sahara, VII-IV millennia BP). In: Wadi TeshuinatPalaeoenvironment and prehistory in south-western Fezzan (Libyan Sahara). Survey and excavations in the Tadrart Acacus, Erg Uan Kasa, Messak Settafet and Edeyen of Murzuq, 1990-1995, edited by Cremaschi, M. and di Lernia, S., pp. 107-122, Firenze: All'Insegna del Giglio.

Mercuri, A., 1999, Palynological analysis of the Early Holocene sequence. The Uan Afuda cave, Hunter-Gatherer societies of Central Sahara, Arid Zone Archaeology, 1, pp. 149-253.

Mercuri, A. M., 2008, Human influence, plant landscape evolution and climate inferences from the archaeobotanical records of the Wadi Teshuinat area (Libyan Sahara). Journal of Arid Environments, 72, pp. 1950-1967, 10.1016/j.jaridenv.2008.04.008.

Mercuri, A. M., Fornaciari, R., Gallinaro, M., Vanin, S. and di Lernia, S., 2018, Plant behaviour from human imprints and the cultivation of wild cereals in Holocene Sahara. Nature plants, $\mathbf{4}$, pp. 71-81, 10.1038/s41477-017-0098-1.

Messerli, B., 1972, Formen und Formungsprozesse in der Hochgebirgsregion des Tibesti, Hochgebirgsforschung/High mountain research 2, Tibesti - Zentrale Sahara, Arbeiten aus der Hochgebirgsregion, Wagner, Innsbruck-München, pp. 23-86.

Messerli, B. and Winiger, M., 1992, Climate, Environmental Change, and Resources of the African Mountains from the Mediterranean to the Equator. Mountain Research and Development, 12(4), pp. 1-315, 10.2307/3673683.

Meusel, H. and Jäger, E., 1992, Vergleichende Chorologie der zentraleuropäischen Flora. Stuttgart New York: Fischer.

Moore, P., Webb, J. and Collinson, M., 1991, Pollen analysis - the treatment of samples, London: Blackwell Science.

Nakagawa, T., Brugiapaglia, E., Digerfeldt, G., Reille, M., de Beaulieu, J.-L. and Yasuda, Y., 1998, Dense-media separation as a more efficient pollen extraction method for use with organic sediment/deposit samples: comparison with the conventional method. Boreas, 27, pp. 15-24, 10.1111/j.1502-3885.1998.tb00864.x.

Neumann, K., 1989, Holocene vegetation of the Eastern Sahara: charcoal from prehistoric sites. The African Archaeological Review, 7, pp. 97-116, 10.1007/BF01116839.

Ozenda, P., 1991, Flore et vegetation du Sahara. Paris: CNRS.

Pachur, H.-J. and Altmann, N., 2006, Die Ostsahara im Spätquartär. Heidelberg: Springer.

Parker, A.G., Eckersley, L., Smtih, M. M., Goudie, M. M., Stokes, S., Ward, S., White, K. and Hodson, M.J., 2004, Holocene vegetation dynamics in the northeastern Rub' al-Khali desert, Arabian Peninsula: a phytolith, pollen and carbon isotope study. Journal of Quaternary Science, 19(7), pp. 665-676, 10.1002/jqs.880. 
Pausata, F.S.R., Messori, G. and Zhang, Q., 2016, Impacts of dust reduction on the northward expansion of the African monsoon during the Green Sahara period. Earth and Planetary Science Letters, 434, pp. 298-307, 10.1016/j.epsl.2015.11.049.

Piotrowska, N., Bluszcz, A., Demske, D., Granoszewski, W. and Heumann, G., 2004, Extraction and AMS radiocarbon dating of pollen from Lake Baikal sediments. Radiocarbon, 46(1), pp. 181-187, 10.1017/S0033822200039503.

Prentice, I., Jolly, D. and BIOME 6000, 2000, Mid-Holocene and glacial-maximum vegetation geography of the northern continents and Africa. Journal of Biogeography, 27(3), pp. 507-519, 10.1046/j.1365-2699.2000.00425.x.

Qin, F., Wang, Y.-F., Ferguson, D., Chen, W.-L., Li, Y.-M., Zhe Cai, Z., Wang, Q., Ma, H.-Z. and Li, C.-S., 2015, Utility of surface pollen assemblages to delimit Eastern Eurasian steppe types. PLos ONE, 10(3), pp. e0119412, 10.1371/journal.pone.0119412.

Quézel, P., 1958, Contribution à l'étude de la flore et de la végétation du Borkou et du Tibesti. Mission botanique au Tibesti. Université d'Alger, Institut de recherches Sahariennes, pp. 99-303.

Quézel, P., 1959, La végétation de la zone nord-occidentale du Tibesti. Travaux de l'Institut de Recherches sahariennes, Université d'Alger, 18, pp. 75-107.

Quézel, P., 1965, La végétation du Sahara, du Tchad à la Mauritanie. Stuttgart : Fischer.

Quézel, P., 1964, Largeau. Carte international du tapis végétal. Institut géographique national, Tchad.

Railsback, L.B., Brook, G.A., Liang, F., Marais, E., Cheng, H. and Edwards, R.L., 2016, A multi-proxy stalagmite record from northwestern Namibia of regional drying with increasing global-scale warmth over the last $47 \mathrm{kyr}$ : The interplay of a globally shifting ITCZ with regional currents, winds, and rainfall. Palaeogeography, Palaeoclimatology, Palaeoecology, 461, pp. 109-121, 10.1016/j.palaeo.2016.08.014.

Regnéll, J. and Everitt, E., 1996, Preparative centrifugation - a new method for preparing pollen concentrates suitable for radiocarbon dating by AMS. Vegetation History and Archaeobotany, 5, pp. 201-205, 10.1007/BF00217497.

Reille, M., 1992, Pollen et spores d'Europe et d'Afrique du Nord, Marseille : Laboratoire de Botanique Historique et Palynologie.

Ritchie, J., Eyles, C. and Haynes, C., 1985, Sediment and pollen evidence for an early to midHolocene humid period in the eastern Sahara. Nature, 314, pp. 352-355, 10.1038/314352a0.

Ritchie, J., 1987, A Holocene pollen record from Bir Atrun, northwest Sudan. Pollen et Spores, 24(4), pp. 391-410.

Ritchie, J., 1994, Holocene pollen spectra from Oyo, northwestern Sudan: problems of interpretation in a hyperarid environment. The Holocene, 4(1), pp. 9-15, 10.1177/095968369400400102.

Ritchie, J. and Haynes, C., 1987, Holocene vegetation zonation in the eastern Sahara. Nature, 330, pp. 645-647, 10.1038/330645a0.

Rogerson, M., Dublyansky, Y., Hoffmann, D., Luetscher, M., Töchterle, P. and Spötl, C., 2019, Enhanced Mediterranean water cycle explains increased humidity during MIS 3 in North Africa. Climate of the Past, 15, pp. 1757-1769, 10.5194/cp-15-1757-2019.

Rossignol, M. and Maley, J., 1969, L'activité hors de France des palynologues et paléobotanistes français du Quaternaire. Etudes Francaises sur le Quaternaire, pp. 265-274.

Schulz, E., 1987, Die holozäne Vegetation der Zentralen Sahara (N-Mali, N-Niger, SW-Libyen). Palaeoecology of Africa, 18, pp. 143-161.

Schulz, E., 1991, Holocene environments in the Central Sahara. Hydrobiologia, 214, pp. 359-365, 10.1007/BF00050971.

Schulz, E., Hachicha, T., Marquer, L., Pomel, S., Salzmann, U. and Abichou, A., 2014, The distant chant. Climate reconstruction and landscape history. The last two millennia in southeast Tunisia. Zentralblatt für Geologie und Paläontologie, 1(1), pp. 355-386, 10.1127/zgpI/2014/03550386 . 
Skinner, C. B and Poulsen, C. J., 2016, The role of fall season tropical plumes in enhancing Saharan rainfall during the African Humid Period. Geophysical Research Letters, 43, pp. 349-358, 10.1002/2015GL066318.

Soulié-Märsche, I., Bieda, S., Lafond, R., Maley, J., Baitoudji, M., Vincent, P. and Faure, H., 2010, Charophytes as bio-indicators for lake level high satdn at 'Trou au Natron', Tibesti, Chad, during the Late Pleistocene. Global and Planetary Change, 72, pp. 334-340, 10.1016/ j.gloplacha.2010.05.004.

Stockmarr, J., 1971, Tablets with spores used in absolute pollen analysis. Pollen et Spores, 13, pp. 615-621.

Subally, D. and Quézel, P., 2002, Glacial or interglacial: Artemisia, a plant indicator with dual responses. Review of Palaeobotany and Palynology, 120(1-2), pp. 123-130, 10.1016/S00346667(01)00143-9.

Thinon, M., Ballouche, A. and Reille, M., 1996, Holocene vegetation of the central Saharan mountains: the end of a myth. The Holocene, 6(4), pp. 457-462, 10.1177/0959683696006 00408 .

Vandergoes, M. J., Prior, C. A., 2003, AMS dating of pollen concentrates - A methodological study of Late Quaternary sediments from South Westland, New Zealand. Radiocarbon, 45(3), pp. 479-491, 10.1017/S0033822200032823.

van Neer, W., Alhaique, F., Wouters, W., Dierickx, K., Gala, M., Goffette, Q., Mariani, G., Zerboni, A. and di Lernia, S., 2020, Aquatic fauna from the Takarkori rock shelter reveals the Holocene central Saharan climate and palaeohydrography. PLoS ONE, 15(2), pp. e0228588, 10.1371/journal.pone.0228588.

Vezey, E. L., Watson, L. E., Skvarla, J. J. and Estes, J.R., 1994, Plesiomorphic and apomorphic pollen structure characteristics of Anthemideae (Asteroideae: Asteraceae). American Journal of Botany, 81, pp. 648-657, 10.1002/j.1537-2197.1994.tb15496.x.

Wesche, K., Ambarli, D., Kamp, J., Török, P., Treiber, J. and Dengler, J., 2016, The Palaearctic steppe biome: a new synthesis. Biodiversity and Conservation, 25, pp. 2197-2231, 10.1007/s10531-016-1214-7.

Watrin, J., Lézine, A.-M., and Hély, C., 2009, Plant migration and ecosystems at the time of the "green Sahara". Comptes Rendus Geosciences, 341, pp. 656-670, 10.1016/j.crte.2009.06.007.

Wickens, G., 1967, Jebel Marra. The flora of Jebel Marra (Sudan Republic) and its geographical affinities. Royal Botanic Gardens, Kew. Kew Bulletin additional series, 5, pp. 1-368.

Wininger, M., 1972, Die Bewölkungsverhältnisse der zentralsaharischen Gebirge aus Wettersatellitenbildern. Hochgebirgsforschung/High mountain research 2, Tibesti - zentrale Sahara, Arbeiten aus der Hochgebirgsregion, Wagner, Innsbruck-München, pp. 87-120. 


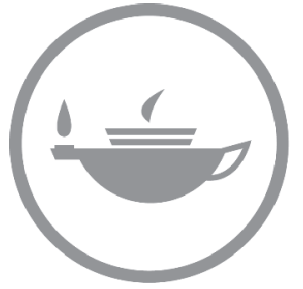

Taylor \& Francis Taylor \& Francis Group http://taylorandfrancis.com 